\title{
Tuber Depth and Yield Response of Tiger Nut (Cyperus esculentus) to Soil Texture and Rates of Poultry and Pig Manure
}

\author{
Thomas O. FABUNMI*, Joyce U. AMALAHU \\ Federal University of Agriculture, Department of Plant Physiology and Crop Production, Abeokuta, Ogun State \\ Nigeria; tomdeji@yahoo.com (*correspondingauthor); evajoyousjoyce@gmail.com
}

\begin{abstract}
A pot experiment was conducted to evaluate tuber depth and weight of tiger nut produced in loamy fine sand and sandy clay soil using 0, 200, 300 or $400 \mathrm{~g}$ per pot of poultry or pig manure in a $2 \times 2 \times 4$ factorial experiment arranged in completely randomized design and replicated three times. Total tuber weight and weight of tubers at $10 \mathrm{~cm}$ were significantly increased by application of manure compared with the control. Significant interaction of soil texture $\mathrm{X}$ manure types $\mathrm{X}$ manure rates was recorded on weight of tubers at $20 \mathrm{~cm}$. Percentage of tubers at $0-10 \mathrm{~cm}$ was $90.6-92.1 \%$ (91.5-93.6\% tuber weight); while 6.68$8.96 \%$ of the tubers $(5.49-8.47 \%$ tuber weight) were harvested between $10-20 \mathrm{~cm}$ soil depth; only $0-0.94 \%$ of the tuber weight was harvested beyond $20 \mathrm{~cm}$ depth. Pig manure had positive effect on tiger nut productivity on loamy fine sand and sandy clay soil, while with poultry manure tiger nut productivity was enhanced on sandy clay soil; $300 \mathrm{~g}$ of pig or poultry manure produced similar weight of tiger nut tubers and is considered optimum for tiger nut productivity. Sandy clay and loamy fine sand had similar effect on depth and yield of tiger nut. More than $99 \%$ of the tubers were confined to $0-20 \mathrm{~cm}$ soil depth. Information on how deep the tubers of tiger nut can grow in soil of different texture and fertility status will enhance precise harvesting.
\end{abstract}

Keywords: manure; soil texture; tiger nut; tuber-depth

\section{Introduction}

Tiger nut (Cyperus esculentus) is a tuber crop belonging to the family cyperaceae. It produces edible tubers that are between $0.3-1.9 \mathrm{~cm}$ in diameter. The tuber is rich in dietary fiber, carbohydrate (Adejuyitan, 2011) and protein (Oladele and Aina, 2007; Belewu and Abodunrin, 2008). It is also a rich source of oil, iron and calcium (Oladele and Aina, 2007). In spite of its numerous economic and health benefits, this crop has not gained wide recognition globally and in some areas it is regarded as a weed, especially among crop scientists. However, in Spain it is a cherished crop and is used in producing tiger nut milk called horchata de chufa. Tiger nut status as a crop is gradually increasing. Many food scientists have reported its importance as a food crop and its potential in meeting different nutritional challenges. Tiger nut can be used to produce milk which is a good substitute for cow milk (Gambo and Da'u, 2014) and according to Sanful (2009), the result of sensory evaluation revealed that yoghurt from pure cow milk and the composite (tiger nut milk and cow milk) were similar in almost all quality attributes. Research and scientific efforts directed at its production is, however, very limited.
One of the constraints associated with the production of tiger nut is the higher labor requirement associated with the manual harvest of the tubers (Teiteh and Ofori, 1998). The tubers are numerous and small in size, thus extra effort is required to pick a great percentage and not to leave them in the soil. Depth of growth of the tubers in the soil must be ascertained for effective harvesting. Soil texture has been reported to have influenced root growth of different crops and an increase in soil compactness has been reported to have resulted in decreased root size, higher concentration of roots in the upper soil as well as resulting in lower rooting depth and a greater distance between roots (Lipiec et al., 2003). Soil fertility is affected by soil texture. The concentrations of $\mathrm{P}, \mathrm{Ca}$, and $\mathrm{Mg}$ in leaves of potato were higher in sandy soil compared to clay soil; while P fertilization increased plant growth, the amount of $\mathrm{P}$ accumulated in the shoot and tuber yield in potato cultivated in the clay soil was higher than in the sandy soil (Martins et al., 2018). Use of animal manure in crop production has currently regained its popularity; this is because maintenance and improvement of soil fertility using manures is more ecofriendly and produces more healthy food compared with synthetic fertilizers. Poultry manure and swine manure are readily available and have been shown 
284

to be rich in nutrients required for productivity of crop plants. Poultry manure application to a field over a period of 10 years was reported to have resulted in higher values of the biological index of fertility of soil (Kobierski $e t$ al., 2017). Similarly, significant increases in N (up to 50\%) and P (up to $80 \%$ ) were observed following addition of chicken manure to spinach (Dikinya and Mufwanzala, 2010) while the application of poultry manure increased available nutrients, increased nutrient uptake and improved dry matter yield in soybean (Soremi et al., 2017). Awosika et al. (2014) reported that pig manure improved soil and crop (tomato) N, P, K, Ca and Mg. Pig manure also increased okra leaf nutrient $\mathrm{N}, \mathrm{P}, \mathrm{K} \mathrm{Ca}$ and $\mathrm{Mg}$ content, while the nutrients increased with application of manure (Akanbi $e t$ al., 2007). It is therefore important to evaluate how deep the tubers of tiger nut can grow in the soil under varied soil texture and fertility conditions in order to be more precise in its harvest and to reduce loss of yield through retention of these relatively small tubers in the soil at harvest.

The study had the following objectives:

1. To evaluate the effect of two contrasting soil textures on depth of tuber in the soil and tuber yield of tiger nut.

2. To evaluate the effect of rates of poultry and pig manure on the depth of tuber and yield performance of tiger nut.

\section{Materials and Methods}

\section{Location of the experiment and experimental design}

The experiment was carried out in the College of Plant Science and Crop Production in the Federal University of Agriculture Abeokuta, Nigeria between May-August, 2017. The trial was a $2 \times 2 \times 4$ factorial in a Completely Randomized Design (CRD), replicated 3 times. Two soils of contrasting texture (loamy fine sandy and sandy clay), two sources of manure (poultry manure and pig manure) and four rates $(0 \mathrm{~g}, 200 \mathrm{~g}, 300 \mathrm{~g}$ and $400 \mathrm{~g})$ per pot of each manure type were utilized.

\section{Collection of planting materials}

Soils (loamy fine sand and sandy clay) were obtained from the university farm. Forty-five kilogram $(45 \mathrm{~kg})$ of each soil type was weighed into 24 disposable bags to give a total of 48 bags of both soils; this formed the 48 experimental units. Air dried poultry manure and pig manure were obtained from the university farm while the tigernut tubers were purchased from the local market. Samples of soils and manures were then taken for laboratory analysis. The manure rates per pot equates approximately to $0,10,15$ and 20 , using the standard that a hectare furrow slice contains 2,242 tons $\left(2.242 \times 10^{6} \mathrm{Kg}\right)$ of soil.

\section{Pot preparation and planting}

Different rates of pig manure and poultry manure were applied to each pot, depending on the treatment. Tiger nut tubers were sorted to obtain uniform tubers, soaked in water for 24 hours after which the tubers were pre sprouted in saw dust for 7 days. Five pre-sprouted tubers were planted per pot.

\section{Data collection}

Data were collected, starting from 2 weeks after planting (WAP) and at 2 week intervals; on plant height and number of leaves per plant. At harvest a calibrated meter rule was used to mark the sides of each pot at 10, 20 and 30 $\mathrm{cm}$ from the top. A sharp knife was used to cut the bag at the side first up to the $10 \mathrm{~cm}$ mark. The soil in the bag and the tubers were then scooped into a $5 \mathrm{~mm}$ sieve from the surface to the $10 \mathrm{~cm}$ mark; by this action, all the tubers in the top $10 \mathrm{~cm}$ were collected. The same process was repeated for the $20 \mathrm{~cm}$ and the $30 \mathrm{~cm}$ depth. Hence tuber yield, tuber size (large medium and small), number and weight of tubers at varying depth $(0-10,10-20$ and $20-30$ $\mathrm{cm}$ from the soil surface) were taken. Tubers greater than or equal to $15 \mathrm{~mm}$ in diameter were classified as large, while those that were less than less than $10 \mathrm{~mm}$ were categorized as small, medium sized tubers were those between these two range. This was done by using $10 \mathrm{~mm}$ and $15 \mathrm{~mm}$ sieves.

\section{Data analysis}

Data collected were subjected to analysis of variance (ANOVA) significant means were separated using least significant difference (LSD), using GENSTAT statistical package.

\section{Results} trial

Physical and chemical properties of the soil used for the

Table 1 presents the physical and chemical analysis of both soils used in this study. Loamy fine sand had higher content of N, P, Ca, Mg, Na and Zn, while Sandy clay had higher $\mathrm{K}, \mathrm{Fe}$ and $\mathrm{Cu}$ content.

\section{Chemical analysis of the poultry and pig manure used for the trial}

Table 2 presents the chemical analysis of the poultry and pig manure used in this experiment. While pig manure was slightly higher in $\mathrm{N}$, the $\mathrm{K}$ content in poultry manure was more than twice of that present in pig manure. Similarly, poultry manure also had higher total $\mathrm{P}$ content relative to pig manure. Poultry manure also had higher Mn content while pig manure was higher in $\mathrm{Fe}, \mathrm{Cu}$ and $\mathrm{Zn}$.

\section{Effect of soil texture and rates of poultry and pig manure on plant height and number of leaves of tiger nut}

Plant height and number of leaves of tiger nut plants, as influenced by soil texture and rates of poultry and pig manure are presented in Table 3. Higher plant height and number of leaves were recorded at 5 and 7 weeks after planting (WAP) respectively, on loamy fine sand relative to sandy clay soil $(\mathrm{p}<0.05)$. There was a significant difference in number of leaves due to soil type. Tiger nut plants raised with pig manure were taller $(\mathrm{p}<0.05)$ and had more leaves than those raised with poultry manure at 5 and 7 WAP, and 7 WAP, respectively. All rates of manure produced plants that were significantly taller with more leaves compared with the control plots at 2 and 5 WAP for plant height and 2 WAP for number of leaves. There was a significant interaction between type and rates of manure on plant height at 7 WAP; while the interaction between soil texture 
and manure rates was significant for number of leaves at 7 WAP (Table 3).

Interaction of types and rates of manure on plant height of tiger nut at $7 W A P$

Table 4 presents the interaction between types and rates of manure on plant height of tiger nut plants at 7 WAP. The application of $400 \mathrm{~g}$ of pig manure produced plants that were significantly taller than plants from all other treatments.

Interaction of types of manure and soil texture on number of leaves of tiger nut

Interaction between types of manure and soil texture on number of leaves of tiger nut plants is presented in Table 5 . The application of pig manure on sandy clay soil led to the production of 2 additional leaves per plant at 7 WAP, compared with pig manure on loamy fine sand or poultry manure on both soil types.
Effect of type of soil texture and rate of poultry and pig manure on number of large, medium and small tubers of tiger nut at 10,20 and $30 \mathrm{~cm}$ depth

Table 6 shows the effect of soil texture and rate of poultry and pig manure on number of large, medium and small tubers of tiger nut at 10,20 and $30 \mathrm{~cm}$ depth of soil at harvest. Soil texture and manure type had no significant effect on number of tiger nut of different sizes at various depths; however, the application of $300 \mathrm{~g}$ of manure per pot led to the production of more large tubers at the $10 \mathrm{~cm}$ soil depth. The number of large tubers decreased when rates of manure was increased to $400 \mathrm{~g}$ per pot (Table 6). The number of tubers of all sizes was decreased at the $10 \mathrm{~cm}$ depth when no manure was applied. Significant interactions were recorded between manure and soil texture on number of large and medium sized tubers at $10 \mathrm{~cm}$ soil depth. The interaction between soil texture and rate of manure was also significant on number of small sized tuber produced at the $20 \mathrm{~cm}$ soil depth (Table 6).

Table 1. Physical and chemical properties of soil used in this study

\begin{tabular}{|c|c|c|}
\hline \multicolumn{3}{|c|}{ Textural class } \\
\hline & Sandy clay & Loamy fine sand \\
\hline $\mathrm{Ca}$ & $5.83 \mathrm{cmol}$ & $7.03 \mathrm{cmol}$ \\
\hline $\mathrm{Mg}$ & $1.52 \mathrm{cmol}$ & $1.84 \mathrm{cmol}$ \\
\hline $\mathrm{Na}$ & $0.3 \mathrm{cmol}$ & $0.86 \mathrm{cmol}$ \\
\hline $\mathrm{K}$ & $0.46 \mathrm{cmol}$ & $0.2 \mathrm{cmol}$ \\
\hline $\mathrm{Mn}$ & $22.45 \mathrm{mg} \mathrm{kg}-1$ & $46.03 \mathrm{mg} \mathrm{kg}-1$ \\
\hline $\mathrm{Fe}$ & $15.55 \mathrm{mg} \mathrm{kg}-1$ & $4.82 \mathrm{mg} \mathrm{kg}-1$ \\
\hline $\mathrm{Cu}$ & $1.21 \mathrm{mg} \mathrm{kg}-1$ & $0.49 \mathrm{mg} \mathrm{kg}-1$ \\
\hline $\mathrm{Zn}$ & $3.36 \mathrm{mg} \mathrm{kg}-1$ & $3.74 \mathrm{mg} \mathrm{kg}-1$ \\
\hline $\mathrm{pH}$ (water) & 6.68 & 7.25 \\
\hline Sand & $54.40 \%$ & $84.40 \%$ \\
\hline Silt & $7.40 \%$ & $5.40 \%$ \\
\hline Clay & $38.20 \%$ & $10.20 \%$ \\
\hline $\mathrm{Al}+\mathrm{H}$ & $0.7 \mathrm{cmol}$ & $0.05 \mathrm{cmol}$ \\
\hline ECEC & $8.18 \mathrm{cmol}$ & $9.98 \mathrm{cmol}$ \\
\hline Base saturation & $99.14 \%$ & $99.50 \%$ \\
\hline Total N & $0.055 \%$ & $0.063 \%$ \\
\hline Total Org C & $0.61 \%$ & $0.59 \%$ \\
\hline Av.P & $6.33 \%$ & $8.13 \%$ \\
\hline
\end{tabular}

Table 2. Chemical analysis of poultry and pig manure used in this study

\begin{tabular}{ccc}
\hline & Poultry Manure & Pig Manure \\
\hline $\mathrm{pH}$ & 7.32 & 8.58 \\
$\mathrm{Ca} \%$ & 9.93 & 16.23 \\
$\mathrm{Mg} \%$ & 1.94 & 1.54 \\
$\mathrm{Na} \%$ & 1.23 & 0.41 \\
$\mathrm{~K} \%$ & 1.16 & 0.44 \\
\hline Total N $\%$ & 0.78 & 0.93 \\
\hline Org C $\%$ & 13.46 & 18.51 \\
\hline Total P mg kg-1 & 4591.32 & 3580.58 \\
\hline Mn mg kg-1 & 667.34 & 592.31 \\
\hline Fe mg kg-1 & 5726.14 & 8864.25 \\
\hline Cu mg kg-1 & 84.43 & 120.4 \\
\hline Zn mg kg-1 & 366.45 & 578.91 \\
\hline C $/ \mathrm{N}$ (ratio $)$ & 17.26 & 19.9 \\
\hline
\end{tabular}


Table 3. Effect of soil texture and rates $\left(\mathrm{g} \mathrm{pot}^{-1}\right)$ of poultry and pig manure on plant height and number of leaves of tiger nut plants at 2,5 and 7 weeks after planting (WAP). Values are a mean of 5 plants

\begin{tabular}{|c|c|c|c|c|c|c|}
\hline & \multicolumn{3}{|c|}{ Plant height $(\mathrm{cm})$} & \multicolumn{3}{|c|}{ Number of leaves } \\
\hline & $2 \mathrm{WAP}$ & $5 \mathrm{WAP}$ & $7 \mathrm{WAP}$ & $2 \mathrm{WAP}$ & $5 \mathrm{WAP}$ & $7 \mathrm{WAP}$ \\
\hline \multicolumn{7}{|l|}{ Soil texture } \\
\hline Sandy clay & 21.37 & 37.31 & 45.56 & 6.96 & 8.04 & 7.42 \\
\hline Loamy fine sand & 19.94 & 43.45 & 47.90 & 7.33 & 7.54 & 8.42 \\
\hline LSD & NS & 2.779 & NS & NS & NS & 0.576 \\
\hline \multicolumn{7}{|l|}{ Manure } \\
\hline Pig & 19.32 & 42.73 & 49.04 & 7.17 & 7.71 & 8.25 \\
\hline Poultry & 21.99 & 38.03 & 44.43 & 7.12 & 7.88 & 7.58 \\
\hline LSD & 1.808 & 2.779 & 3.304 & NS & NS & 0.576 \\
\hline \multicolumn{7}{|l|}{ Rate } \\
\hline 0 & 16.62 & 32.04 & 43.21 & 5.92 & 6.67 & 7.25 \\
\hline 200 & 19.64 & 40.23 & 47.27 & 7.58 & 7.50 & 8.33 \\
\hline 300 & 20.07 & 43.54 & 45.67 & 7.67 & 8.42 & 8.17 \\
\hline 400 & 26.27 & 45.68 & 50.79 & 7.42 & 8.58 & 7.92 \\
\hline LSD & 2.556 & 3.930 & 4.672 & 0.874 & 1.230 & NS \\
\hline Manure X Soil & NS & NS & NS & NS & NS & 0.814 \\
\hline Rate X Soil & NS & NS & NS & NS & NS & NS \\
\hline Rate X Manure & NS & NS & 6.607 & NS & NS & NS \\
\hline $\begin{array}{c}\text { Rate X Soil X } \\
\text { Manure }\end{array}$ & NS & NS & NS & NS & NS & NS \\
\hline
\end{tabular}

NS= Not significant

Table 4. Interaction between types and rates of manure $\left(\mathrm{g} \mathrm{pot}^{-1}\right)$ on plant height $(\mathrm{cm})$ of tiger nut at 7 WAP. Values are a mean of 5 plants

\begin{tabular}{cccccc}
\hline Manure & Rate & 0 & 200 & 300 & 400 \\
\hline Pig & & 44.75 & 49.50 & 44.82 & 57.05 \\
Poultry & 41.67 & 45.02 & 46.52 & 44.50 \\
LSD & & 6.607 & & \\
\hline
\end{tabular}

Table 5. Interaction of types of manure and soil texture on number of leaves of tiger nut plants at 7 WAP. Values are a mean of 5 plants

\begin{tabular}{cccc}
\hline Manure & Soil & Loamy fine sand & Sandy clay \\
\hline Pig & & 7.25 & 9.25 \\
Poultry & 7.58 & 7.58 \\
LSD & 0.814 & \\
\hline
\end{tabular}

Table 6. Effect of soil texture and rates $\left(\mathrm{g}\right.$ pot $\left.{ }^{-1}\right)$ of poultry and pig manure on number of large, medium and small tiger nut tubers at 10,20 and $30 \mathrm{~cm}$ soil depth at harvest

\begin{tabular}{|c|c|c|c|c|c|c|c|c|c|}
\hline & \multicolumn{3}{|c|}{ Large } & \multicolumn{3}{|c|}{ Medium } & \multicolumn{3}{|c|}{ Small } \\
\hline Treatment & 10 & 20 & 30 & 10 & 20 & 30 & 10 & 20 & 30 \\
\hline \multicolumn{10}{|l|}{ Soil texture } \\
\hline Sandy clay & 3.08 & 0.23 & 0.00 & 4.33 & 0.44 & 0.00 & 23.29 & 2.12 & 0.06 \\
\hline $\begin{array}{l}\text { Loamy fine } \\
\text { sand }\end{array}$ & 5.21 & 0.25 & 0.04 & 5.96 & 0.56 & 0.25 & 18.06 & 1.44 & 0.25 \\
\hline LSD & NS & NS & NS & NS & NS & NS & NS & NS & NS \\
\hline \multicolumn{10}{|l|}{ Manure } \\
\hline Pig & 4.62 & 0.27 & 0.02 & 5.00 & 0.54 & 0.22 & 21.46 & 2.08 & 0.23 \\
\hline Poultry & 3.67 & 0.21 & 0.02 & 5.29 & 0.46 & 0.03 & 19.90 & 1.48 & 0.08 \\
\hline LSD & NS & NS & NS & NS & NS & NS & NS & NS & NS \\
\hline \multicolumn{10}{|l|}{ Rate } \\
\hline 0 & 2.25 & 0.08 & 0.00 & 2.33 & 0.04 & 0.25 & 10.08 & 0.38 & 0.00 \\
\hline 200 & 3.21 & 0.42 & 0.00 & 5.67 & 0.67 & 0.06 & 20.50 & 1.88 & 0.21 \\
\hline 300 & 6.71 & 0.17 & 0.00 & 5.96 & 0.88 & 0.19 & 24.54 & 2.96 & 0.29 \\
\hline 400 & 4.42 & 0.29 & 0.08 & 6.62 & 0.42 & 0.00 & 28.71 & 1.92 & 0.12 \\
\hline LSD & 2.699 & NS & NS & 2.585 & 0.424 & NS & 8.048 & 1.287 & NS \\
\hline Manure X Soil & 2.699 & NS & NS & 2.64 & NS & NS & NS & NS & NS \\
\hline Rate X Soil & NS & NS & NS & NS & NS & NS & NS & NS & NS \\
\hline $\begin{array}{c}\text { Rate X } \\
\text { Manure }\end{array}$ & NS & NS & NS & NS & NS & NS & NS & NS & NS \\
\hline $\begin{array}{c}\text { Rate X Soil X } \\
\text { Manure }\end{array}$ & NS & NS & NS & NS & NS & NS & NS & 2.573 & NS \\
\hline
\end{tabular}


Interactions between manure types and soil texture on number of large and medium sized tubers of tiger nut at $10 \mathrm{~cm}$ soil depth

Table 7 presents the interactions between manure types and soil texture on number of large and medium sized tubers of tiger nut at $10 \mathrm{~cm}$ soil depth. A similar number of large and medium sized tubers were produced at $10 \mathrm{~cm}$ soil depth with pig manure application on sandy clay and loamy fine sand soils, even though number of tubers harvested at $10 \mathrm{~cm}$ soil depth was slightly higher $(p>0.05)$ in loamy fine sand relative to sandy clay soil. Both large and medium sized tubers were greater in number at $10 \mathrm{~cm}$ depth of sandy clay soil compared to loamy fine sand soil, when poultry manure was applied.

Interaction between types and rates of manure and soil texture on number of small sized tubers of tiger nut at $20 \mathrm{~cm}$ soil depth

The interaction between types and rates of manure and soil texture on number of small sized tubers of tiger nut at
$20 \mathrm{~cm}$ soil depth showed that the highest number of small sized tubers was produced at $300 \mathrm{~g}$ manure rate in sandy clay and loamy fine sand soil by the application of pig manure and poultry manure, respectively. Generally, at all rates of poultry and pig manure, higher numbers of small sized tubers were produced in loamy fine sand relative to sandy clay, except at $300 \mathrm{~g}$ using pig manure (Table 8 ).

Effect of soil texture and rates of poultry and pig manure on tuber weight of tiger nut at 10,20 and $30 \mathrm{~cm}$ depth of soil

Table 9 presents the effect of soil texture and rates of poultry and pig manure on tuber weight of tiger nut at 10 , 20 and $30 \mathrm{~cm}$ depth of soil at harvest. While soil texture and manure types had no significant effect on the total weight and weight of tiger nut tubers at varying soil depths, manure rates significantly affected these attributes. Significant interactions between manure and soil texture were also recorded for total weight of tubers and weight of tubers at $10 \mathrm{~cm}$ soil depth and between manure rate and soil at the 20 cm depth.

Table 7. Interaction between manure type and soil texture on number of large and medium sized tubers of tiger nut at $10 \mathrm{~cm}$ depth

\begin{tabular}{cccccc}
\hline & & \multicolumn{3}{c}{ Number of tubers at $10 \mathrm{~cm}$ soil depth } \\
\cline { 3 - 6 } & & \multicolumn{3}{c}{ Large } & Medium \\
\hline Manure & Soil texture & Loamy fine sand & Sandy clay & Loamy fine sand & Sandy clay \\
Pig & 5.29 & & 4.52 & 5.54 & 4.46 \\
Poultry & 1.33 & & 5.83 & 3.12 & 7.12 \\
LSD & & 2.699 & & & 2.640 \\
\hline
\end{tabular}

Table 8. Interaction between types and rates of manure and soil texture on number of small sized tubers of tiger nut at $20 \mathrm{~cm}$ soil depth. Values are a mean of 5 plants

\begin{tabular}{|c|c|c|c|c|c|}
\hline \multirow[b]{2}{*}{ Rate(g/pot) } & \multirow[b]{2}{*}{ Soil } & \multicolumn{2}{|c|}{ Pig manure } & \multicolumn{2}{|c|}{ Poultry manure } \\
\hline & & Loamy fine sand & Sandy clay & Loamy fine sand & Sandy clay \\
\hline 0 & & 0.67 & 0.00 & 0.67 & 0.17 \\
\hline 200 & & 4.17 & 1.50 & 0.50 & 2.00 \\
\hline 300 & & 1.83 & 6.25 & 6.75 & 1.33 \\
\hline 400 & & 2.33 & 2.50 & 3.75 & 0.50 \\
\hline LSD & & & & & \\
\hline
\end{tabular}

Table 9. Effect of soil texture and rates of poultry and pig manure on total tuber weight and weight of tiger nut tubers at 10, 20 and $30 \mathrm{~cm}$ depth of soil at harvest. Values are a mean of 5 plants

\begin{tabular}{|c|c|c|c|c|}
\hline & \multirow{2}{*}{ Tuber weight (g/plant) } & \multicolumn{3}{|c|}{ Tuber weight (g/plant) at different soil depth } \\
\hline & & $10 \mathrm{~cm}$ & $20 \mathrm{~cm}$ & $30 \mathrm{~cm}$ \\
\hline \multicolumn{5}{|l|}{ Soil texture } \\
\hline Sandy clay & 11.90 & 11.08 & 0.82 & 0.00 \\
\hline Loamy fine sand & 15.13 & 14.21 & 0.79 & 0.03 \\
\hline LSD & NS & NS & NS & NS \\
\hline \multicolumn{5}{|l|}{ Manure } \\
\hline $\operatorname{Pig}(G)$ & 14.38 & 13.32 & 0.94 & 0.036 \\
\hline Poultry (P) & 12.65 & 11.96 & 0.66 & 0.06 \\
\hline LSD & NS & NS & NS & NS \\
\hline \multicolumn{5}{|l|}{ Rate(g/pot) } \\
\hline 0 & 6.41 & 6.26 & 0.16 & 0.00 \\
\hline 200 & 13.95 & 12.86 & 1.01 & 0.027 \\
\hline 300 & 17.28 & 15.88 & 1.29 & 0.032 \\
\hline 400 & 16.40 & 15.57 & 0.76 & 0.014 \\
\hline LSD & 5.498 & 5.511 & 0.681 & NS \\
\hline Manure X Soil & 3.888 & 5.51 & NS & NS \\
\hline Rate X Soil & NS & NS & NS & NS \\
\hline Rate X Manure & NS & NS & NS & NS \\
\hline Rate X Soil X Manure & NS & NS & 1.361 & NS \\
\hline
\end{tabular}


288

Interaction between soil texture and manure types on tuber weight of tiger nut per plant and weight of tubers harvested at $10 \mathrm{~cm}$ depth of soil

The interaction between soil texture and manure types on tuber weight per plant and weight of tubers of tiger nut harvested at $10 \mathrm{~cm}$ depth of soil are presented in Table 10. Total tuber weight per plant and weight of harvested tubers at $10 \mathrm{~cm}$ soil depth were similar in loamy fine sand and sandy clay soil when pig manure was applied even though higher values (not significant) were recorded for both attributes in loamy fine sand $(p>0.05)$; however significantly higher weight of tubers per plant and weight of harvested tubers at $10 \mathrm{~cm}$ soil depth were recorded in sandy clay soil compared with loamy fine sand when poultry manure was applied. Thus higher weights of tubers were obtained in sandy clay soil with application of poultry manure relative to pig manure application at $10 \mathrm{~cm}$ soil depth (Table 10).

Interaction between types and rates of manure and soil texture on tuber weight (g/plant) of tiger nut at $20 \mathrm{~cm}$ soil depth

Table 11 presents the interaction between types and rates of manure and soil texture on tuber weight $\left(\mathrm{g}\right.$ plant $\left.{ }^{-1}\right)$ of tiger nut at $20 \mathrm{~cm}$ soil depth at harvest. Weight of tubers harvested at $20 \mathrm{~cm}$ soil depth was similar across soil textures and manure types in the control plot and at $400 \mathrm{~g}$ per pot manure rate, even though slightly higher (not significant) values were recorded in loamy fine sand compared with sandy clay soil. At $200 \mathrm{~g}$ per pot application rate, significantly higher weight was recorded in loamy fine sand soil when pig manure was applied compared with the control and at $300 \mathrm{~g}$ per pot application rate, application of pig manure to sandy clay soil and poultry manure to loamy fine sand soil produced higher weight of tubers at $20 \mathrm{~cm}$ $(\mathrm{p}<0.05)$ compared to the control plot.

Percentage and weight of tiger nut tubers at different soil depth as affected by soil texture and rates of pig and poultry manure

Table 12 presents percentage and weight of tiger nut tubers at different soil depths as affected by soil texture and rates of pig and poultry manure. There was no significant difference in percentage and weight of tubers between the soil texture types, manure types and rates at 10 and $20 \mathrm{~cm}$ soil depth; at $30 \mathrm{~cm}$ soil depth, however, loamy fine sand had higher percentage weight of tubers compared with sandy clay soil. No significant interaction was recorded. The result showed that $90.62-92.21 \%$ of the number of tubers (91.53 - 93.56\% of the tuber weight) were harvested between $0-10 \mathrm{~cm}$ soil depth; $6.68-8.96 \%$ of the number of tubers (5.49-8.47\% of the tuber weight) were harvested between $10-20 \mathrm{~cm}$ soil depth and $0.42-1.10 \%$ of the number of tubers $(0.00-0.94 \%$ of the tuber weight) were harvested between $20-30 \mathrm{~cm}$ soil depth.

Table 10. Interaction between soil texture and manure types on tuber weight of tiger nut per plant and weight of tubers harvested at $10 \mathrm{~cm}$ depth of soil. Values are a mean of 5 plants

\begin{tabular}{|c|c|c|c|c|c|}
\hline \multirow{2}{*}{ Manure } & \multirow{2}{*}{ Soil } & \multicolumn{2}{|c|}{ Weight of tubers (g/plant) } & \multicolumn{2}{|c|}{ Weight of harvested tubers $(\mathrm{g} / \mathrm{plant})$ at $10 \mathrm{~cm}$ soil depth } \\
\hline & & Loamy fine sand & Sandy clay & Loamy fine sand & Sandy clay \\
\hline Pig & & 15.16 & 13.59 & 14.26 & 12.38 \\
\hline Poultry & & 8.63 & 16.66 & 7.89 & 16.04 \\
\hline LSD & & 5.498 & 5.511 & 2.45 & 0.73 \\
\hline 400 & & 1.04 & 0.91 & 0.87 & 0.24 \\
\hline LSD & & & & & \\
\hline
\end{tabular}

Table 11. Interaction between types and rates of manure and soil texture on tuber weight $(\mathrm{g} / \mathrm{plant})$ of tiger nut at $20 \mathrm{~cm}$ soil depth at harvest. Values are a mean of 5 plants

\begin{tabular}{cccccc}
\hline \multirow{2}{*}{ Rate } & \multicolumn{2}{c}{ Soil } & \multicolumn{3}{c}{ Poultry manure } \\
\cline { 2 - 5 } & Loamy fine sand & Sandy clay & Loamy fine sand & Sandy clay \\
\hline 0 & 0.27 & 0.06 & 0.18 & 0.14 \\
200 & 1.62 & 1.33 & 0.45 & 1.22 \\
300 & 0.66 & 2.11 & 2.45 & 0.73 \\
400 & 1.04 & 0.91 & 0.87 & 0.24 \\
LSD & & & 1.269 & & \\
\hline
\end{tabular}

Table 12. Percentage and weight of tiger nut tubers per plant at different depth as affected by soil texture and rates of poultry or pig manure. Values are a mean of 5 plants

\begin{tabular}{|c|c|c|c|c|c|c|}
\hline \multirow{2}{*}{ Treatment } & \multicolumn{3}{|c|}{ Percentage number of tubers per plant } & \multicolumn{3}{|c|}{ Percentage weight of tubers per plant } \\
\hline & $10 \mathrm{~cm}$ & $20 \mathrm{~cm}$ & $30 \mathrm{~cm}$ & $10 \mathrm{~cm}$ & $20 \mathrm{~cm}$ & $30 \mathrm{~cm}$ \\
\hline \multicolumn{7}{|l|}{ Soil } \\
\hline Sandy clay & 90.62 & 8.96 & 0.42 & 91.53 & 8.47 & 0.00 \\
\hline Loamy fine sand & 92.21 & 6.68 & 1.10 & 93.56 & 5.49 & 0.94 \\
\hline LSD & NS & NS & NS & NS & NS & $0.842^{*}$ \\
\hline \multicolumn{7}{|l|}{ Manure } \\
\hline $\operatorname{Pig}(G)$ & 91.18 & 7.83 & 0.99 & 92.54 & 6.66 & 0.79 \\
\hline Poultry (P) & 91.65 & 7.82 & 0.53 & 92.56 & 7.29 & 0.15 \\
\hline LSD & NS & NS & NS & NS & NS & NS \\
\hline \multicolumn{7}{|l|}{ Rate(g/pot) } \\
\hline 0 & 94.90 & 5.10 & 0.00 & 94.97 & 5.03 & 0.00 \\
\hline 200 & 88.77 & 9.55 & 1.68 & 92.49 & 6.93 & 0.58 \\
\hline 300 & 89.63 & 9.64 & 0.73 & 89.98 & 9.58 & 0.44 \\
\hline 400 & 92.38 & 7.00 & 0.63 & 92.76 & 6.38 & 0.86 \\
\hline LSD & NS & NS & NS & NS & NS & NS \\
\hline Manure. Soil & NS & NS & NS & NS & NS & NS \\
\hline Rate. Soil & NS & NS & NS & NS & NS & NS \\
\hline Rate. Manure & NS & NS & NS & NS & NS & NS \\
\hline Rate. Soil. Manure & NS & NS & NS & NS & NS & NS \\
\hline
\end{tabular}




\section{Discussion}

Nutrient content of soil can vary according to soil texture. The result of the soil chemical analysis in this study is comparable to the report of Martins et al. (2018) that the concentration of $\mathrm{P}, \mathrm{Ca}$, and $\mathrm{Mg}$ in leaves of potato was higher in sandy soil relative to clay soil. They, however, observed that P accumulated in the shoot and tuber of potato in both soils, but that the trend was higher in the potato cultivated in clay soil rather than in sandy soil.

The $\mathrm{K}$ content of the poultry manure in this study was higher than in pig manure. This result is similar to the report of Odedina et al. (2011), however, by comparison between the two manure types, the $\mathrm{N}$ content and the $\mathrm{P}$ content are at variance with the report of Odedina $e t a l$. (2011). The $\mathrm{pH}$ of the chicken manure was similar to that reported by Huang et al. (2017) but the $\mathrm{pH}$ of pig manure was higher than the 6.63 reported by the same authors. The C: $\mathrm{N}$ ratios of the manures were higher than that reported by Huang et al. (2017), however, a higher ratio was also reported by these authors for pig manure compared to poultry manure. This implies that poultry manure is more likely to be readily mineralized than pig manure. Variation in nutrient contents of manures is, however, expected and is affected by the breed of the animal, the feed intake and the production systems, among other factors.

Production of taller plants of tiger nut with the application of $400 \mathrm{~g}$ of pig manure compared with plants raised with other rates of pig manure and all rates of poultry manure suggest the effectiveness of pig manure in releasing nutrient for the growth of tiger nut. This is because both soils used in this study were low in soil nitrogen that is one of the most limiting plant nutrients in the tropical environment. Taller plants from pig manure can be attributed to the fact that the pig manure used in this study had higher nitrogen content compared with the poultry manure. Mooleki et al. (2002) reported that under an annual application regime, a significant elevation of preseeding available $\mathrm{N}$ in the $0-60 \mathrm{~cm}$ soil depth and increased grain yield and protein content with increasing application rates of liquid swine manure were observed in wheat, Argentine canola (Brassica napus L.) and barley. Similarly, Akanbi et al. (2007) reported that pig manure increased okra leaf nutrient $\mathrm{N}, \mathrm{P}, \mathrm{K} \mathrm{Ca}$ and $\mathrm{Mg}$ content, and the nutrients increased with application of manure; Awosika et al. (2014) also reported that pig manure improved soil and crop N, P, K, Ca and Mg.

More leaves produced by tiger nut plants with the application of pig manure in sandy clay soil could also be attributed to higher nutrient $\mathrm{N}$ present in pig manure relative to poultry manure. Pig manure application was reported to have increased okra leaf nutrient $\mathrm{N}, \mathrm{P}, \mathrm{K}, \mathrm{Ca}$ and $\mathrm{Mg}$ contents (Akanbi et al., 2007).

Higher production of large and medium sized tubers at $10 \mathrm{~cm}$ soil depth, when poultry manure was applied, and in sandy clay, soil can be due to higher quantity of $\mathrm{P}$ present in the poultry manure compared with the pig manure. Poultry manure also had higher $\mathrm{K}$ content. This result agrees with the findings of Martins et al. (2018) who reported that P fertilization increased plant growth, the amount of $\mathrm{P}$ accumulated in the shoot and tuber yield in sandy and clay soils, but that the trend was stronger in the potato cultivated in the clay soil than in the sandy soil. Furthermore, the relatively more compactness of the sandy clay soil compared with the loamy fine sand could also account for the higher concentration of bigger tubers in the upper layer of the soil. Increase in soil compactness results in higher concentration of roots in the upper soil, lower rooting depth and crop yield increase in moderately compacted soil (Lipiec et al., 2003).

The highest number of small sized tubers obtained at 20 $\mathrm{cm}$ soil depth with application of $300 \mathrm{~g}$ of pig and poultry manure to sandy clay and loamy fine sand, respectively, suggest that $300 \mathrm{~g}$ per pot of both manures would be adequate for the production of tiger nut. This result suggests that even though the use of pig and poultry manure in tiger nut production increased productivity, a bench mark equivalent to $300 \mathrm{~g}$ per pot (about 15 tons ha $\mathrm{a}^{-1}$ ) as used in this study need not be exceeded. This corroborates an earlier report that the annual application of high rates ( $400 \mathrm{~kg}$ total $\mathrm{N} \mathrm{ha}^{-1}$ ) of liquid swine manure had no agronomic advantage over the lower rates (100 to $200 \mathrm{~kg}$ total $\mathrm{N} \mathrm{ha}^{-1}$ ), but that it may result in higher residual nitrates in the soil thus increasing potential for environmental pollution (Mooleki, 2002).

In this study, soil texture and manure types had no significant effect on the total weight and weight of tiger nut tubers at varying soil depth, however, manure rates did significantly affect these attributes. Apart from the genetic potential of the crop, the yield and yield attributes of tiger nut at different depths is influenced more by the rates of poultry or pig manures, and not the manure itself in both soil types. This result can be attributed to higher quantity of nutrient released by higher rates of manure. This further suggests that the same rate ( $300 \mathrm{~g}$ per pot in this study) of either of the manure can be used to produce tiger nut. The implication of this is that in a reasonable fertile soil, more of the tubers would be harvested closer to the soil surface.

In this study, higher total tuber weight of tiger nut and higher weight of tubers harvested at $10 \mathrm{~cm}$ when poultry manure was applied in sandy clay soil relative to the yield from loamy fine sand with the same manure could be because of the lower C:N ratio of the poultry manure and more compactness of the sandy clay soil. Release of nutrients would have been faster with the poultry manure and retention of the released nutrients for crop uptake would have been more in the sandy clay soil than in the loamy fine sand soil. This is likely because the sandy clay soil was more compact than loamy fine sand soil. Increase in soil compactness results in higher concentration of roots in the upper soil and crop yield increase in moderately compacted soil (Lipiec et al., 2003).

In this study, higher weight of tiger nut recorded in both sandy clay and loamy fine sand at $20 \mathrm{~cm}$ depth when $300 \mathrm{~g}$ of either pig manure or poultry manure was applied support the observation that rates equivalent to $300 \mathrm{~g}$ per pot of pig or poultry manure was adequate for the production of tiger nut in sandy clay or loamy fine sand soil. This further suggests that both soils are adequate for tiger nut production, however, more labor is required when sandy clay soil is used for production, especially at harvest, because of the bulkiness of the soil.

Results obtained on the percentage weight and number of tubers of tiger nut harvested at different soil depth 
290

implies that the depth of tubers of tiger nut is more genetically controlled than it is influenced by the soil texture and manure type or rate (although weight of harvested tubers at $10 \mathrm{~cm}$ responded positively to rates of manure application in this study). This result also suggests that once the harvester used in harvesting tiger nut is $10-20 \mathrm{~cm}$ deep about $99 \%$ of the tubers will have been harvested. This shows that tuber production of tiger nut is within the top 0$15 \mathrm{~cm}$ depth of the soil. This finding corroborates earlier report that tubers of tiger nut can develop in soil depth around $30 \mathrm{~cm}$, but that most occur in the top or upper part. Maduka and Ire (2018) also reported that tiger nut tubers could reach about six inches $(15 \mathrm{~cm})$ depth in soil. This study, however quantifies the proportion of tubers present at different soil depths unlike the report of Maduka and Ire (2018).

\section{Conclusions}

Tiger nut productivity was enhanced on sandy clay soil when poultry manure was applied, while pig manure had a positive effect on tiger nut production on loamy fine sand and sandy clay soil; $300 \mathrm{~g}$ per pot (equivalent to about 15 tons $\mathrm{ha}^{-1}$ ) of both manures was optimum for tiger nut production. Tuber depth of tiger nut was similar in both sandy clay and loamy fine sand soil. In poor soil, tubers are more restricted to the surface. More large tubers will occur between $0-10 \mathrm{~cm}$ in more fertile soil. Up to $93.56 \%$ of tubers were confined to $0-10 \mathrm{~cm}$ of the soil, while $5.49 \%$ were harvested at $10-20 \mathrm{~cm}$ and $0.95 \%$ at $30 \mathrm{~cm}$ depth. This information will enhance precision in harvesting and reduce losses at harvest.

\section{Conflicts of interest}

The authors declare that there are no conflicts of interest related to this article.

\section{References}

Adejuyitan JA (2011). Tiger nut processing: its food uses and health benefits. American Journal of Food Technology 6(3):197-201.

Akanbi AI, Akanbi OS, Ojeniyi SO (2007).Effect of pig manure on nutrient composition, growth and yield of Okra. Nigerian Journal of Soil Science 17(1):109-112.

Awosika OE, Awodun MA, Ojeniyi SO (2014). Comparative effect of pig manure and NPK fertilizer on agronomic performance of tomato (Lycopersicon esculentum Mill.). American Journal of Experimental Agriculture4(11):1330-1338.

Belewu MA, Abodunrin OA (2008). Preparation of Kunnu from unexploited rich food source: Tiger nut (Cyperusesculentus). Pakistan Journal of Nutrition 7(1):109-111.
Dikinya O, Mufwanzala N (2010). Chicken manure-enhanced soil fertility and productivity: Effects of application rates. Journal of Soil Science and Environmental Management 1(3):46-54.

Gambo A, Dảu A (2014). Tiger nut (Cyperusesculentus): Composition, products, uses and health benefits- A review. Bayero Journal of Pure and AppliedSciences 7(1):56-61.

Huang J, Yu Z, Gao H, Yan X, Chang J, Wang C, Zhang L (2017). Chemical structures and characteristics of animal manures and composts during composting and assessment of maturity indices. PLoS One 12(6):e0178110.

Kobierski M, Bartkowiak A, LemanowiczJ, Piekarczyk M (2017).Impact of poultry manure fertilization on chemical and biochemical properties of soils. Plant Soil Environment 63(12): 558-563.

Lipiec J, Medvedev VV, Birkas M, Dumitru E, Lyndina TE, Rousseva S, Fulajtár E (2003). Effect of soil compaction on root growth and crop yield in Central and Eastern Europe. International Agrophysics 17(2):61-69.

Maduka N, Ire FS (2018). Tiger nut plant and useful application of tiger nut tubers (Cyperusesculentus)- A review. Current Journal of Applied Science and Technology 29(3):1-23.

Martins LJD, Soratto RP, FernandesAM, Dias PHM (2018). Phosphorus fertilization and soil texture affect potato yield. Revista Caatinga 31(3):541-550.

MoolekiSP, Schoenau JJ, Hultgreen G, Wen G, CharlesJL(2002). Effect of rate, frequency and method of liquid swine manure application on soil nitrogen availability, crop performance and $\mathrm{N}$ use efficiency in eastcentral Saskatchewan. Canadian Journal of Soil Science 82(4):457-467.

Odedina JN, Odedina SA, Ojeniyi SO (2011).Effect of types of manure on growth and yield of Cassava (Manihot esculenta, Crantz). Researcher 3(5):1-8.

Oladele AK, Aina OJ (2007). Chemical composition and functional properties of flour produced from two varieties of tiger nut (Cyperus esculentus). African Journal of Biotechnology 6(21):2473-2476.

Sanful RE (2009). The use of tiger nut (Cyperus esculentus), cow milk and their composite as substrates for yoghurt production. Pakistan Journal of Nutrition 8(6):755-758.

Soremi AO, Adetunji MT, Adejuyigbe CO, BodundeJG, AzeezJO (2017). Effects of poultry manure on some soil chemical properties and nutrient bioavailability to soybean. Journal of Agriculture and Ecology Research International 11(3):1-10.

Teiteh JP, Ofori E (1998). A baseline survey of tiger nut (Cyperus esculentus) production in the KwahuSoqth District of Ghana. Ghana Journal of Agricultural Science 31(2):211-216. 